\title{
Ecological Toxicology Research
}

Effects of Heavy Metal and Organohalogen Compounds 


\title{
Environmental Science Research
}

\section{Editorial Board}

\author{
Alexander Hollaender \\ The University of Tennessee \\ Knoxville \\ and Associated Universities, Inc. \\ Washington, D.C. \\ Ronald F. Probstein \\ Massachusetts Institute of Technology \\ Cambridge, Massachusetts

\section{E. S. Starkman} \\ General Motors Technical Center \\ Warren, Michigan

\section{Bruce L. Welch} \\ Friends Medical Science Research Center, Inc. \\ and \\ The Johns Hopkins University School of Medicine \\ Baltimore, Maryland
}

\author{
Volume 1 - INDICATORS OF ENVIRONMENTAL QUALITY \\ Edited by William A. Thomas $\bullet 1972$ \\ Volume 2 - POLLUTION: ENGINEERING AND SCIENTIFIC SOLUTIONS \\ Edited by Euval S. Barrekette $\bullet 1973$ \\ Volume 3 - ENVIRONMENTAL POLLUTION BY PESTICIDES \\ Edited by C. A. Edwards $\bullet 1973$ \\ Volume 4 - MASS SPECTROMETRY AND NMR SPECTROSCOPY IN \\ PESTICIDE CHEMISTRY \\ Edited by Rizwanul Haque and Francis J. Biros $\bullet 1974$ \\ Volume 5 - BEHAVIORAL TOXICOLOGY \\ Edited by Bernard Weiss and Victor G. Laties • 1975 \\ Volume 6 - ENVIRONMENTAL DYNAMICS OF PESTICIDES \\ Edited by Rizwanul Haque and V. H. Freed $\bullet 1975$ \\ Volume 7 - ECOLOGICAL TOXICOLOGY RESEARCH: EFFECTS OF HEAVY \\ METAL AND ORGANOHALOGEN COMPOUNDS \\ Edited by A. D. Mclntyre and C. F. Mills $\bullet 1975$
}

A Continuation Order Plan is available for this series. A continuation order will bring delivery of each new volume immediately upon publication. Volumes are billed only upon actual shipment. For further information please contact the publisher. 


\section{Ecological Toxicology Research}

\section{Effects of Heavy Metal and Organohalogen Compounds}

Proceedings of a NATO Science Committee Conference

Edited by

\section{A. D. McIntyre}

Department of Agriculture and Fisheries for Scotland Aberdeen, Scotland

and

C. F. Mills

The Rowett Research Institute

Aberdeen, Scotland 


\section{Library of Congress Cataloging in Publication Data}

Nato Science Committee Conference on Eco-toxicology, Mont Gabriel, Quebec, 1974.

Ecological toxicology research.

(Environmental science research; v. 7)

"Held under the auspices of the NATO Science Committee."

Includes bibliographical references and index.

1. Heavy metals-Environmental aspects-Congresses. 2. Organohalogen compounds-Environmental aspects-Congresses. 3. Pollution-Toxicology-Congresses. 4. Ecology-Congresses. I. McIntyre, A. D. II. Mills, Colin Frederick, 1926-

III. North Atlantic Treaty Organization. Science Committee. IV. Title. QH545.M45N37 1974 $574.2^{\circ} 4$

Proceedings of the NATO Science Committee Conference on Eco-Toxicology held at Mont Gabriel, Quebec, Canada, May 6-10, 1974

@1975 Plenum Press, New York

Softcover reprint of the hardcover 1st edition 1975

A Divison of Plenum Publishing Corporation 227 West 17th Street, New York, N.Y. 10011

United Kingdom edition published by Plenum Press, London

A Division of Plenum Publishing Company, Ltd.

Davis House (4th Floor), 8 Scrubs Lane, Harlesden, London, NW10 6SE, England

All rights reserved

No part of this book may be reproduced, stored in a retrieval system, or transmitted, in any form or by any means, electronic, mechanical, photocopying, microfilming, recording, or otherwise, without written permission from the Publisher 


\section{Foreword}

The Conference on the Ecotoxicity of Heavy Metals and Organohalogen Compounds was held under the auspices of the NATO Science Committee as part of its continuing effort to promote the useful progress of science through international cooperation.

Science Committee Conferences are deliberately designed to focus attention on unsolved problems, with invited participants providing a variety of complementary expertise. Through intensive group discussion they seek to reach a consensus on assessments and recommendations for future research emphases, which it is hoped will be of value to the larger scientific community. The subjects treated in previous Conferences have been as varied as science itself-e.g., computer software, chemical catalysis, oceanography, and materials and energy research.

This volume presents an account of a meeting which evolved from studies within the Science Committee's advisory panel on Eco-Sciences. Environmental monitoring of toxic substances from industrial and agricultural sources is producing a growing volume of data on the quantities of such substances in terrestrial and aquatic milieus. Before this information can be used to assess biological effects, knowledge is required of the chemical form of the pollutants, the mechanisms by which they enter and move through organisms, their concomitant transformations, the nature of the toxic reactions within tissues, and the way in which the physiology and behavior of individuals is affected.

The meeting brought together a number of specialists who critically evaluated their present knowledge and identified those areas of research in which accelerated progress seemed particularly critical.

Some forty-seven papers, either in the form of reprints or specially written reviews, were contributed by the participants for advance circulation. The availability of this material precluded the need for lengthy introductory presentations and permitted rapid initiation of spirited interdisciplinary discussions. All 
participants gave generously and enthusiastically of their wisdom and knowledge during the week of the meeting, and we extend to them our deep gratitude.

Special thanks go to Dr. A. McIntyre and Dr. C. Mills, for their diligent efforts as Chairman and Co-Chairman of the meeting, to their colleagues on the Organizing Committee, Prof. S. Dalgaard-Mikkelsen, Dr. R. W. Durie, Dr. E. D. Goldberg, Prof. D. H. Remmer, and Prof. R. Truhaut, for their wise counsel, and to the leaders and recorders of the working groups as listed, for their indispensable dedication.

Grateful acknowledgment is also made of the considerable assistance provided to this Conference by Environment Canada. Its concrete and spiritual support contributed significantly to any success which has been achieved.

Eugene G. Kovach

Deputy Assistant Secretary General for Scientific Affairs 


\section{Preface}

The well-documented increase in pollution from a wide variety of sources presents a potential threat to living organisms, and the term "ecotoxicology" is useful in referring to the study of the distribution and effects of toxic substances in major organic assemblages, from the habitats of mountain ranges to the communities of oceanic abysses. In attempting to assess such effects the ecologist is faced with a bewildering variety of problems. The history of ecological studies is relatively short, and the ecologist has not in the past been particularly concerned with pathology and so has sparse foundations on which to build. Further, the vast assemblage of species with which he has to deal, and their great diversity of reactions, compounds the problem.

By contrast, the medical or veterinary scientist is in an enviable position. He has behind him a long tradition of research providing a detailed understanding of the small number of species on which he is required to concentrate his attention. Consequently he has been able to approach the newer problems of pollution with a substantial background knowledge of a suitable type on which to draw for an assessment of effects on man and domestic animals, and with a significant body of appropriate expertise to guide the design and execution of research.

It is thus reasonable to suggest that the ecologist working in the pollution field would have much to learn from those concerned with these other sciences and with the study of domesticated species. This consideration formed a major part of the rationale behind the NATO Science Committee conference on aspects of ecotoxicology upon which this volume is based. The remit given to participants was as follows:

"The primary task of this interdisciplinary meeting on the ecotoxicology of heavy metals and organohalogen compounds is to identify those areas of this subject in which inadequate knowledge of the processes influencing entry, metabolism, and toxic action of these pollutants is presently hindering assessment of the significance of the hazards they create within ecosystems. 
"Specialists from several disciplines have been brought together with the specific objective of facilitating detailed discussion of those physical, biological, and biochemical processes which affect the response to these toxic materials and which thus complicate the interpretation of pollutant survey data.

"It is intended that the report of this meeting shall clearly highlight those areas in which further research activity is particularly desirable to achieve realistic assessment of the hazards presented by individual heavy metals and organohalogen compounds in the environment."

This volume presents an account of the proceedings of the conference. Part I contains the text of eight lectures presented during plenary sessions designed to set the scene for the later activities of specialist Working Groups. Part II contains seven papers selected from among those submitted for circulation to participants before the meeting, these papers illustrating, in differing detail, the wide scope of scientific enquiry that is relevant to the ultimate assessment of the fate and effects of potentially toxic materials present in the environment.

Part III contains the Working Group Reports and their recommendations. Since these were set out in the style of the individual group leaders and rapporteurs, and reflect the separate approaches of each group, no editorial attempt has been made to reduce them to uniformity.

There was general agreement that participation in this multidisciplinary meeting was a stimulating and provocative experience. If this volume reflects the enthusiasm with which the remit of the meeting was handled and concentrates future attention around those topics so clearly felt to be currently hindering assessment of the biological significance of some pollutants, it will have served its purpose. We are confident that it clearly reflects the need for more closely integrated multidisciplinary research effort if satisfactory progress toward control of the adverse effects of pollutants is to be maintained.

$$
\text { C. F. Mills }
$$

Rowett Research Institute

Bucksburn, Aberdeen, Scotland

A. D. McIntyre

DAFS Marine Laboratory

Aberdeen, Scotland

Cochairmen: NATO Science Committee Conference on

Ecotoxicity of Heavy Metals and Organohalogen Compounds 


\section{Contents}

\section{PART I • PLENARY PAPERS}

\section{Chapter 1}

Ecotoxicology-A New Branch of Toxicology: A General

Survey of Its Aims, Methods, and Prospects . . . . . . . . 3

R. Truhaut

\section{Chapter 2}

Some Effects of Pollutants in Terrestrial Ecosystems . . . . . . . . 25

William H. Stickel

\section{Chapter 3}

Aspects of Heavy Metal and Organohalogen Pollution

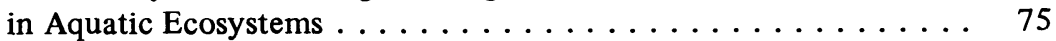

Bostwick H. Ketchum, V. Zitko, and D. Saward

Chapter 4

Species Variation in the Metabolism of Some Organic Halogen Compounds 91 R. T. Williams, P. C. Hirom, and A. G. Renwick

\section{Chapter 5}

Reactive Metabolites of Organohalogen Compounds . . . . . . . . . 107

James R. Gillette

\section{Chapter 6}

Active Sites of Biological Macromolecules and Their

Interaction with Heavy Metals . . . . . . . . . . . . 123

G. L. Eichhorn 


\section{PART II • INVITED PAPERS}

\section{Chapter 7}

Behavior of Mercury in Natural Systems and Its Global Cycle $\ldots \ldots \ldots .145$

R. Wollast, G. Billen, and F. T. Mackenzie

Chapter 8

Mobilization of Metals in the Dutch Wadden Sea . . . . . . . . 167

J. C. Duinker

Chapter 9

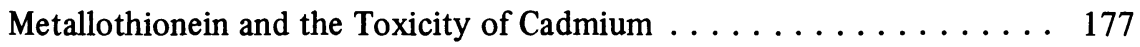

M. Webb

Chapter 10

The Significance of Multielement Analyses in Metal Pollution Studies . . . 187

T. L. Coombs

Chapter 11

Potentially Persistent Industrial Organic Chemicals Other than PCB . . . . 197

V. Zitko

Chapter 12

The Influence of Polychlorinated Biphenyl Compounds on

Hepatic Function in the Rat . . . . . . . . . . . . . . 207

D. J. Ecobichon

Chapter 13

The Accumulation and Excretion of Heavy Metals in Organisms . . . . . 215

Jorma K. Miettinen

\section{PART III • WORKING GROUP REPORTS}

\section{Working Group A}

Entry, Distribution, and Fate of Heavy Metals and

Organohalogens in the Physical Environment . . . . . . . . 233

Working Groups $B / C$

Uptake, Fate, and Action of Heavy Metals and

Organohalogen Compounds in Living Organisms . . . . . . . . . . 257

Working Group D

Movements of Heavy Metals and Organohalogens through Food Chains

and Their Effects on Populations and Communities 
Working Group E

Analytical Methodology . . . . . . . . . . . . . . . . . . 301

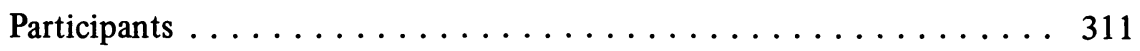

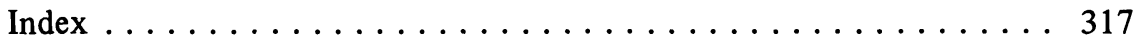

